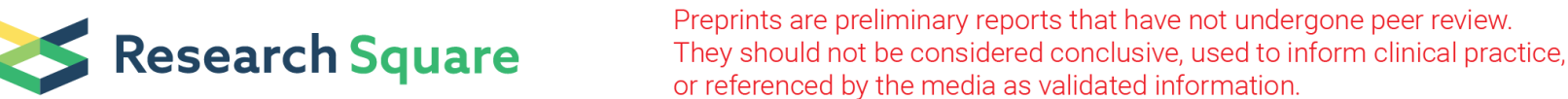

\section{Variability of body build and physiological spinal curvatures of young people in an accelerated longitudinal study}

Jacek Tuz

Slaski Uniwersytet Medyczny w Katowicach

Adam Maszczyk

Akademia Wychowania Fizycznego imienia Jerzego Kukuczki w Katowicach

Anna Zwierzchowska ( $\nabla$ a.zwierzchowska@awf.katowice.pl )

The Jerzy Kukuczka Academy Physical Education https://orcid.org/0000-0002-4284-8697

\section{Research}

Keywords: variability of body build, variability of body posture, spinal curvatures in the sagittal plane

Posted Date: March 4th, 2020

DOI: https://doi.org/10.21203/rs.3.rs-15941/v1

License: (c) (i) This work is licensed under a Creative Commons Attribution 4.0 International License.

Read Full License

Version of Record: A version of this preprint was published at International Journal of Environmental Research and Public Health on July 16th, 2021. See the published version at https://doi.org/10.3390/ijerph18147590. 


\section{Abstract}

Objective : The human body is characterized by the variability of the characteristics of body build, which is expressed in the instability of spinal curvatures, which change during ontogeny. This phenomenon leads to a phylogenetic evolution of the human body build and posture. The aim of the study was to assess the dynamics of the variability of traits and indices of body build and posture and their mutual relations. It was assumed that over the 10-year observation period, a significant variability and relationships will be observed between the characteristics of body build and posture in young adults.

Material and Methods: Between 2006 and 2016, 2,154 women and men aged 19.6 \pm 0.8 were examined (first-year students of the University of Economics in Katowice, Poland). Measurements of basic anthropometric measurements and angular values of lumbar lordosis and thoracic kyphosis were performed. The collected data were analysed statistically and the intergroup and intragroup differences were evaluated (ANOVA with repeated measures). The dynamics of variability (by building time series) and absolute and single-base increments were determined.

Results : The body build of young men and women in the period of ontogenetic stabilization in the study group has changed statistically significantly over the decade. A prediction of the increases in body weight and hip circumference was recorded over a period of 10 years, especially in men. The characteristics of body posture have also undergone a significant progressive change. In women, thoracic kyphosis increased by $96.15 \%$, whereas in men, lumbar lordosis decreased by $52.65 \%$.

Conclusions : Significant sexual differentiation was shown for such characteristics as body height, waist circumference and the angle of lumbar lordosis. The relationships between the characteristics of body build and posture were verified. There was a moderate relationship between the hip circumference and lumbar lordosis in women and a weak relationship between body height and the angle of thoracic kyphosis in men. The characteristics of human body build and posture during the period of ontogenetic stabilization show high non-linear variability, characterized by significant dimorphic differentiation.

\section{Introduction}

The human body, including the spinal curvatures, changes during ontogeny and phylogeny [1, 2], which is reflected by the instability of characteristics and indicators of body build and posture. The period of ontogenetic stabilization between 20 and 40 years of age, accompanied by the inhibition of growth processes and establishment of body proportions does not guarantee discontinuation of the variability of physiological spinal curvatures. This is especially due to the lifestyles, which are an important factor in changing body composition and body build in the coming decades. In this context, the phylogenetic changes observed in the increasing body weight and reducing body height during ontogenesis cannot be ignored [3]. This evolution is evidenced by the results of epidemiological studies, and their authors often indicated in their conclusions further consequences to the structure and functions of the human body, which are conducive to the occurrence of cardiometabolic diseases and joint and spine pain [4-7]. 
Furthermore, it has been proven that there are endogenous posture compensation mechanisms which are a response to the evolution of body build. This process is not always associated with the symptoms of disease [8]. The human body has great adaptability, especially since the phylogenetic changes observed are spread over time. In this context, changes in physiological spinal curvature are the subject of research and thorough observations, particularly when they contribute to abnormal posture and/or pain [9]. At the same time, the physiological spinal curvatures are highly labile, which is recorded even in the daily cycles, and the authors of these observations indicated their dependence on the mental status, lifestyle and temporal pathologies that may also determine these characteristics [10-13].

A disorder of the spatial system of the body posture may generate a state of spinal pathology, which however is not always of a direct character. The sagittal balance is based on lumbar lordosis [14], with its decrease and/or increase considered to be the event initiating the cascade of compensatory mechanisms [15], also of the pathological nature. Furthermore, it is the part of the spine that is most often the target of surgical and physiotherapeutic interventions $[16,17]$. Asthenia of body build, overweight, obesity, reduced muscle tension, disproportionately high body fat compared to muscle mass are only some of the factors that coexist in the formation of spinal pathology [18].

The relationships of the physiological spinal curvatures with body build and body composition have been the area of explorations in few scientific studies of phylogenetics, especially with relation to the young people in the period of ontogenetic stabilization.

The aim of the study was to evaluate the dynamics of the variability of characteristics and indices of body build and posture and their mutual relations. It was assumed that over the 10-year observation period, a significant variability and relationship between the characteristics of body build and posture will be observed in young adults.

\section{Material And Methods}

\section{Participants}

The examinations were carried out between 2006 and 2016. They were students $(n=2154)$ of the first year of the Faculty of Economics and Management of the local University of Economics. In total, 1314 women aged 19.7 years $( \pm 0.4)$ and 840 men aged 19.6 years $( \pm 1.2)$ were examined (see Table 1$)$.

\section{Table 1}

Structure of the study group of women and men in the period between 2006 and 2016 


\begin{tabular}{|c|c|c|c|c|c|c|}
\hline \multirow[t]{2}{*}{ Date of examination } & \multicolumn{3}{|c|}{ Women } & \multicolumn{3}{|l|}{ Men } \\
\hline & $\mathrm{N}$ & age $S \pm S D$ & $\min -\max$ & $\mathrm{N}$ & age $S \pm S D$ & $\min -\max$ \\
\hline 2006 & 139 & $19.3 \pm 0.5$ & $17.8-20.7$ & 119 & $19.4 \pm 1.2$ & $18-24$ \\
\hline 2007 & 230 & $19.7 \pm 0.77$ & $17.4-22$ & 152 & $19.7 \pm 1.01$ & $18-23$ \\
\hline 2008 & 131 & $19.5 \pm 0.67$ & $17.8-23.2$ & 99 & $19.1 \pm 0.6$ & $18-22$ \\
\hline 2009 & 99 & $19.9 \pm 0.9$ & $18.2-24.5$ & 40 & $19.6 \pm 1.1$ & $18-24$ \\
\hline 2010 & 167 & $19.6 \pm 0.6$ & 18.3-23.1 & 89 & $19.5 \pm 1.04$ & $19-22$ \\
\hline 2011 & 163 & $19.1 \pm 0.6$ & $18-22$ & 94 & $19.2 \pm 1.06$ & $18-24$ \\
\hline 2012 & 137 & $19.1 \pm 0.7$ & $18-23$ & 71 & $19.1 \pm 0.8$ & $18-23$ \\
\hline 2013 & 62 & $19.6 \pm 0.7$ & $18.2-22.1$ & 23 & $20.3 \pm 1.1$ & $19-23$ \\
\hline 2014 & 59 & $20.1 \pm 0.6$ & $18.8-20.9$ & 72 & $19.1 \pm 0.9$ & $18-23$ \\
\hline 2015 & 75 & $20.3 \pm 1.0$ & $17.7-24.8$ & 52 & $20.4 \pm 0.8$ & $18-23$ \\
\hline 2016 & 52 & $20.3 \pm 0.6$ & 18.7-21.5 & 29 & $20.1 \pm 1.1$ & $17-23$ \\
\hline Total & 1314 & $19.7 \pm 0.4$ & $18.1-22.5$ & 840 & $19.6 \pm 1.2$ & $18.2-23.5$ \\
\hline
\end{tabular}

The students surveyed, representing the average young Caucasian population, were people who were involved in various forms of physical activity, but none of them was actively involved in sport. Furthermore, during the research, they did not report any pain or other diseases that would make it impossible to conduct the research and disturb the homogeneity of the group studied. The inclusion criterion concerned persons who had any locomotor system dysfunction or another disease preventing them from the active participation in physical education classes in a university. The examinations were carried out in the morning in separate rooms on the premises of the university, and they were always carried out by the same two examiners. The subjects were wearing sportswear, without shoes and socks. Beforehand, they were instructed about the purpose of the study and fasted for 2 hours before the measurements.

The research was carried out for the following 10 years at the same university (every year in October) and the same research procedures were used for first-year students. The research was conducted in accordance with the standards contained in the 2008 Declaration of Helsinki, and the students who participated in the examinations gave their written consent. Study participants could withdraw from the test procedure at any time without giving reasons. The first two years of the research were a pilot study and the data collected are included in the analyses of the research project "Diagnostics of the body build, body posture and physical fitness of students", which was approved by resolution of the local bioethics commission No. 5/2008 of 29 April 2008. 


\section{Measurement procedures}

\section{Procedures}

The examinations were conducted in the morning. This was a cohort-sequential design cross-sectional analytical study, and the participants were measured only once. Anteroposterior spinal curvatures were evaluated by means of the Rippstein plurimeter. The plurimeter allows for quick, accurate and inexpensive examinations of children and adolescents' posture in the sagittal and transverse planes in order to complement physical examinations (in e.g. orthopaedics and paediatrics) and rehabilitation. The apparatus enables quick and easy measurements and ensures the reproducibility of the results, even when the examinations are carried out by different examiners. Two values of angular deflection are obtained (read directly from the apparatus): the angle of thoracic kyphosis, measured between the kyphosis peak Th12 and Th1, and the angle of lumbar lordosis, measured between L5 and Th $\mathrm{h}_{12}$. A Vplurimeter was employed to measure thoracic kyphosis and lumbar lordosis, with the patient standing without any postural correction $[13,14]$. Two examiners performed the measurements in order to minimize inter-observer differences, see Fig. 1. The value of $30 \pm 5$ was considered normal kyphosis and lordosis $[14,15]$.

We measured body height (BH), waist and hip circumference (WC and $\mathrm{HC}$ ) [cm]. Body weight (kilograms) was determined using a Tanita BC 420SMA stand-on bioimpedance analyzer (Tanita Corporation, Japan). The study was performed according to a standard protocol recommended by the manufacturer. The participant started examinations in the fasted state, in light clothing, shoeless and without socks, with clean feet. The participants were instructed to fast for at least 2 hours before the measurement. The device samples periods of 5-second resistance values $(\mathrm{Rx})$ and the reactance of their volume (Xc). These data are used as a basis for calculating body composition by a computer program relative to age, sex and body height [16]. Body height measurements were performed using a wall-mounted stadiometer with standard scales and the accuracy of $0.5 \mathrm{~cm}$. Body height was measured to the nearest $\mathrm{mm}$. An anthropometric tape was used over light clothing to measure waist circumference (WC [cm]) and hip circumference $(\mathrm{HC}[\mathrm{cm}])$. Waist circumference was measured between the iliac crest and the rib cage (minimum circumference) whereas hip girth was measured over the greater trochanters (maximum width).

\section{Statistical procedure}

The collected material was subjected to statistical analysis. Arithmetic means and standard deviations were calculated. The Shapiro-Wilk test was used to test the data for normal distribution, whereas the homogeneity of variance was evaluated by means of the Levene's test. The ANOVA analysis of variance with repeated measures was employed to determine intergroup and intragroup differences. Time series were built and absolute and single-base increments as well as single-base indices and variables were determined in order to assess the dynamics of the variability of specific variables. The time series were also used to determine trends and predictive values for lumbar lordosis and thoracic kyphosis. 
Correlations between the analysed variables were calculated using the Spearman's test. The level of statistical significance was set at $p<0.05$.

\section{Results}

It was demonstrated that the gender factor influences dependent variables such as body height, body weight, waist circumference and lumbar lordosis at a level of statistical significance $(p<0.05)$ (see Table 2).

Table 2

Significant gender differences in the analysed characteristics of body build and posture between women and men in 2006-2016

\begin{tabular}{|c|c|c|c|c|c|c|}
\hline \multirow[t]{2}{*}{ Characteristic } & \multicolumn{2}{|c|}{$\operatorname{Men}(n=840)$} & \multicolumn{2}{|c|}{ Women $(n=1314)$} & \multirow[t]{2}{*}{$\mathbf{F}$} & \multirow[t]{2}{*}{$\mathbf{P}$} \\
\hline & $\pm S D$ & $\min .-\max$. & $\pm S D$ & min.-max. & & \\
\hline $\mathrm{BH}[\mathrm{cm}]$ & $180.6 \pm 6.3$ & $161-202$ & $168 \pm 6.1$ & $151.0-189.9$ & 444.498 & $0.001^{*}$ \\
\hline BM [kg] & $74.9 \pm 12.4$ & $49.3-139$ & $58.7 \pm 8.8$ & $39.4-108.5$ & 131.066 & $0.001 *$ \\
\hline WC [cm] & $82 \pm 8.8$ & $52-118$ & $70.9 \pm 6.4$ & $59.0-112.0$ & 44.299 & $0.001^{\star}$ \\
\hline $\mathrm{HC}[\mathrm{cm}]$ & $80 \pm 8.8$ & $70,3 \pm$ & $95.7 \pm 6.6$ & $78.0-132.0$ & 0.375 & 0.544 \\
\hline $\mathrm{KTH}\left[^{\circ}\right]$ & $37.5 \pm 8.5$ & $9-64$ & $35.7 \pm 8.5$ & $15.0-62.0$ & 0.406 & 0.531 \\
\hline LL $\left[^{\circ}\right]$ & $30 \pm 9.4$ & $4-60$ & $34.4 \pm 8.6$ & $10.0-60.0$ & 6.774 & $0.002^{*}$ \\
\hline
\end{tabular}

The analysis of the absolute values of variability over 10 years of observation of the characteristics of body build and body posture in both groups revealed the highest variability for thoracic kyphosis in both groups, and the lowest for body height in both men and women.

An increasing tendency for body height was observed in men, with a simultaneous decrease in hip and waist circumference. Different values were obtained for women, with body height tending to decrease with a simultaneous increase in hip and waist circumferences (Table 3).

Table 3

Increases in absolute values of the body build and body posture of men and women in 2006-2016 


\begin{tabular}{|lllllll|}
\hline Participants & $\mathrm{BH}[\mathrm{cm}]$ & $\mathrm{BM}[\mathrm{kg}]$ & $\mathrm{HC}[\mathrm{cm}]$ & $\mathrm{WC}[\mathrm{cm}]$ & $\mathrm{KTH}\left[^{\circ}\right]$ & $\mathrm{LL}\left[^{\circ}\right]$ \\
\hline Women & -0.37 & 3.62 & 1.14 & 2.96 & 46.87 & 14.64 \\
\hline Men & 0.23 & 1.81 & -2.81 & -1.37 & 43.26 & 12.65 \\
\hline
\end{tabular}

The analysis of relative increments based on time series of observed characteristics of body build and posture in men allowed for the indication of the largest and smallest changes over the decade. Over 10 years of observation, of all the assessed characteristics of body build and body posture of the men studied, only the angle of kyphosis accelerated each year, and the mean value of development of this characteristic in this period was the highest $(\mathrm{KTH} 10=52.65 \%)$ and statistically significant. Furthermore, the highest range of variation among the somatic characteristics was found for hip circumference (HC10 $=30.64 \%)$. The smallest range of variation occurred for body height $(\mathrm{BH} 10=3.13 \%)$.

The analysis of relative increments based on time series in the group of women reveals that the greatest changes over the 10-year observation are observed for the angle of thoracic kyphosis (KTH10 $=96.15 \%$ ) and body weight $\left(\mathrm{BM}_{10}=14.37 \%\right)$.

The smallest changes during the 10-year observation in women were recorded for body height $(\mathrm{BH} 10=$ $3.32 \%$ ). The variability of both the angle of kyphosis and lordosis was statistically significant (Table 4).

Table 4

Relative increments based on chain indices for body posture and body build in men and women [\%].

\begin{tabular}{|lllllll|}
\hline \multirow{2}{*}{$\begin{array}{l}\text { Characteristics of body build } \\
\text { and body posture }\end{array}$} & men & \multicolumn{5}{c|}{ women } \\
\cline { 2 - 8 } & min. & max. & 10 & min. & max. & 10 \\
\hline BH & -1.60 & 1.53 & $3.13 \%$ & -2.14 & 1.18 & $3.32 \%$ \\
\hline BM & -10.13 & 6.84 & $16.97 \%$ & -3.40 & 10.97 & $14.37 \%$ \\
\hline WC & -6.76 & 11.25 & $18.01 \%$ & -2.20 & 11.39 & $13.59 \%$ \\
\hline HC & -24.15 & 6.49 & $30.64 \%$ & -4.57 & 5.89 & $10.46 \%$ \\
\hline LL & -6.00 & 30.01 & $36.01 \%$ & -18.25 & 30.95 & $49.20 \%$ \\
\hline TH & 32.30 & 84.95 & $52.65 \%$ & -5.50 & 90.65 & $96.15 \%$ \\
\hline
\end{tabular}

Analysis of single-base indices in the group of men revealed slight changes in the characteristics of body build. The greatest variability of somatic characteristics was observed in the waist circumference $(-2.3 \%)$, but it was not statistically significant. Similar significant changes, but of an accelerating nature, were recorded for the angle of thoracic kyphosis where the single-base index was 32.8\% (Table 5). 
Table 5

Dynamics of the variability of time series for the characteristics of body build and posture in men [\%] in terms of single-base indices (lj) and variable-base indices (Iz) between 2006 and 2016.

\begin{tabular}{|llll|}
\hline $\begin{array}{l}\text { Characteristics of } \\
\text { body build } \\
\text { and body posture }\end{array}$ & $\begin{array}{l}\text { Variable-base } \\
\text { index } \\
\text { (Iz) }\end{array}$ & $\begin{array}{l}\text { Variable-base index (Iz) } \\
\text { max.[\%] }\end{array}$ & $\begin{array}{l}\text { Single-base index (Ij) until } \\
\text { 2006 [\%] }\end{array}$ \\
\hline Body height & $\begin{array}{l}2012 \text { to } 2011 \\
-3.8\end{array}$ & $\begin{array}{l}2013 \text { to } 2012 \\
4.7\end{array}$ & 1.3 \\
\hline Body mass & 2013 to 2012 & $\begin{array}{l}2012 \text { to } 2011 \\
26.8\end{array}$ & 1.2 \\
\hline $\begin{array}{l}\text { Waist circumference } \\
\text { [cm] }\end{array}$ & $\begin{array}{l}2012 \text { to } 2011 \\
-27.2\end{array}$ & $\begin{array}{l}2011 \text { to } 2010 \\
24.3\end{array}$ & -2.3 \\
\hline $\begin{array}{l}\text { Hip circumference } \\
\text { [cm] }\end{array}$ & 2013 to 2012 & $\begin{array}{l}2012 \text { to } 2011 \\
62.9\end{array}$ & -2.1 \\
\hline LL & -51.6 & 2014 to 2013 & -16.5 \\
\hline Th & 2015 to 2014 & 50.2 & 32.8 \\
\hline
\end{tabular}

The single-base indices in the group of women were also analysed. The greatest variability was recorded in the waist circumference $(10.7 \%)$. The index for the characteristics of body posture shows similar dynamics of variability in the case of thoracic kyphosis (58.9\%). (Table 6).

Table 6

Dynamics of variability of time series for the characteristics of body build and posture in women [\%] in terms of single-base indices (lj) and variable-base indices(Iz) between 2006 and 2016. 


\begin{tabular}{|c|c|c|c|}
\hline $\begin{array}{l}\text { Characteristics of } \\
\text { body build } \\
\text { and body posture }\end{array}$ & $\begin{array}{l}\text { Variable-base } \\
\text { indices } \\
\text { (Iz) min. [\%] }\end{array}$ & $\begin{array}{l}\text { Variable-base index (Iz) } \\
\text { max. [\%] }\end{array}$ & $\begin{array}{l}\text { Single-base index (lj) until } \\
2006 \text { [\%] }\end{array}$ \\
\hline Body height & $\begin{array}{l}\text { from } 2012 \text { to } \\
2011 \\
-3.5\end{array}$ & $\begin{array}{l}\text { from } 2013 \text { to } 2012 \\
3.2\end{array}$ & -0.2 \\
\hline Body mass & $\begin{array}{l}\text { from } 2013 \text { to } \\
2012 \\
-15.3\end{array}$ & $\begin{array}{l}\text { from } 2012 \text { to } 2011 \\
15.2\end{array}$ & 7.9 \\
\hline $\begin{array}{l}\text { Waist circumference } \\
\text { [cm] }\end{array}$ & $\begin{array}{l}\text { from } 2013 \text { to } \\
2012 \\
-12.4\end{array}$ & $\begin{array}{l}\text { from } 2012 \text { to } 2011 \\
10.2\end{array}$ & 10.7 \\
\hline $\begin{array}{l}\text { Hip circumference } \\
\text { [cm] }\end{array}$ & $\begin{array}{l}\text { from } 2013 \text { to } \\
2012 \\
-17.5\end{array}$ & $\begin{array}{l}\text { from } 2014 \text { to } 2013 \\
18.3\end{array}$ & 1.9 \\
\hline LL & $\begin{array}{l}\text { from } 2015 \text { to } \\
2014 \\
-75.1\end{array}$ & $\begin{array}{l}\text { from } 2014 \text { to } 2013 \\
90.7\end{array}$ & 15.1 \\
\hline Th & $\begin{array}{l}\text { from } 2011 \text { to } \\
2010 \\
-42.4\end{array}$ & $\begin{array}{l}\text { from } 2015 \text { to } 2014 \\
85.2\end{array}$ & 58.9 \\
\hline
\end{tabular}

A moderate relationship between body height and the angle of thoracic kyphosis was recorded in the group of men and it was directly proportional (the higher the body height the higher the angle of thoracic kyphosis. Furthermore, a high and statistically significant relationship was observed between the hip circumference and lumbar lordosis in the group of women. This relationship is directly proportional: the larger the hip circumference, the greater the lumbar lordosis (see Table 7). The other assessed characteristics of body build in both groups did not show such a significant relationship with respect to body posture

\section{Table 7}

Correlations of the variables of body build and posture in men and women in a 10-year observation 


\begin{tabular}{|lllll|}
\hline Woriable & $\begin{array}{l}\text { Angle of } \\
\text { kyphosis }\end{array}$ & $\begin{array}{l}\text { Angle of } \\
\text { lordosis }\end{array}$ & $\begin{array}{l}\text { Angle of } \\
\text { kyphosis }\end{array}$ & $\begin{array}{c}\text { Angle of } \\
\text { lordosis }\end{array}$ \\
\hline Height & 0.3 & 0.1 & $0.4^{*}$ & -0.06 \\
\hline Body mass & 0.2 & 0.32 & -0.2 & -0.004 \\
\hline $\begin{array}{l}\text { Waist circumference } \\
\text { [cm] }\end{array}$ & 0.3 & 0.13 & -0.2 & 0.13 \\
\hline Hip circumference [cm] & 0.1 & $0.7^{*}$ & -0.1 & 0.08 \\
\hline *statistical significance at $\mathrm{p}<0.05$ & & & \\
\hline
\end{tabular}

\section{Discussion}

The assessment of the secular trend of overweight and obesity in school children was carried out between 1998 and 2008 in the south of Poland by Mazur et al. (a cross-sectional study) [19]. Significant shifts in the incidence of obesity and overweight were found (decrease in the incidence of obesity and an increase in the incidence of overweight among boys and girls in comparative studies in 1998 and 2008. Similar dynamics of the variability of the characteristics of body build (body height, body weight) were not observed in the presented studies of adults from southern Poland, although the presented studies were collected in subsequent years every year between 2006 and 2016 (single-base index, see Tables 5 and 6).

The concurrent study of Malina provided a small longitudinal component [20], but the results failed to refer to the accelerated longitudinal methodology. Selected characteristics of body build were used only to assess the incidence of overweight and obesity. Furthermore, Lehman et al. [21] analysed temporal changes and secular trends in body height and body weight in German conscripts in an accelerated longitudinal study. Although the research tools were similar, the objectives were already significantly different from those presented in our study. However, the authors of that study stressed the fact of nonlinear variability of trends in the groups studied, which is consistent with our results of the assessed characteristics of body build and posture and the computed indices. Similar variability was demonstrated in a Brazilian study in a similar age group [22].

Observations of the secular trend of both Caucasian, Asian and African-American populations clearly indicated a significant increase in body weight, with a simultaneous tendency to reduce body height regardless of the age groups analysed and the methodology used [23]. The lack of the increase in body height with the simultaneous increase in body weight and acceleration of puberty indicates progressive developmental disharmony [24] The authors usually identify this fact with socio-economic factors, because the higher the economic status, the more sedentary lifestyles and the more dynamic indicated trend. Analysis of the dynamics of time series variability for the characteristics body build and posture 
also supported these theses as we noticed significant differentiation of single-base indices (lj) by gender (lj women: $\mathrm{BH}=0.2 \% ; \mathrm{BM}=7.9 \%$ ), (lj men: $\mathrm{BH}=1.3 \% ; \mathrm{BM}=1.2 \%$ ). Our research supports such statements since both the physical activity and the physical fitness of Polish students has a downward trend and the economic status reveals an upward trend (). Furthermore, such a significant variation in the variability of somatic characteristics observed in relation to gender is confirmed in a study by Tutkuviene et al. 2005, who pointed out that it is a secular trend in women that is particularly noticeable [25]. Our research supports this thesis as the relative mean increase in body mass over 10 years in the observed homogeneous population of young women $(3.62 \mathrm{~kg})$ and men $(1.81 \mathrm{~kg})$ was significantly higher.

The changes in body build observed in our study are not as impressive as in the case of the characteristics of body posture, where relative increases based on chain indices were $\mathrm{KTH}=52.65 \%$ and $\mathrm{LL}=36.01 \%$ for men and $\mathrm{KTH}=96.15 \%$ and $\mathrm{LL}=49.2 \%$ for women. Unfortunately, the lack of similar observations in the available literature does not allow for a broader interpretation of the results. However, the observed variability of the angles of kyphosis and lordosis is statistically significant and much higher compared to somatic characteristics. This fact already confirms how plastic and sensitive the skeletal system of the spine is to changes in body build.

Malina et al. and Lehman et al. [20,21] stressed the importance of the identification of risk factors generating overweight and obesity. However, none of the researchers predicted the effect of variability of BMI (increase) on the physiological spinal curvatures which may result in pathologies. Lehman and Avilla $[21,22]$ evaluated only men. However, a high correlation is observed between the increase in hip circumference and lumbar lordosis in the group of women and a moderate correlation between body height and thoracic kyphosis in the group of men, which in turn affects the occurrence of compensatory changes in the spine and joints [8].

In conclusion, significant sexual differentiation was shown for such characteristics as body height, waist circumference and the angle of lumbar lordosis. Body build and body posture of young people in a longitudinal observation over the decade have changed significantly with an unfavourable tendency to increase body weight. During the 10-year observation, a significant decrease in lumbar lordosis was observed, with the simultaneous deepening of thoracic kyphosis.

\section{Strengths And Weaknesses Of The Study}

The main limitation of the study is the difficulty of discussing the results, as similar relationships have been shown only in causal studies in different groups according to age, physical activity and gender.

The absolute strength of the presented results is their continuous character, methodological repeatability and the fact that the empirical research was carried out over a period of 10 years by the same three examiners. This is of particular importance when concluding on the reliability of physiological measurements of spinal curvature 


\section{Conclusion}

The characteristics of human body build and posture during the period of ontogenetic stabilization show high non-linear variability, characterized by significant dimorphic differentiation. A moderate relationship was found between the hip circumference and lumbar lordosis in women whereas a weak relationship occurred between body height and the angle of thoracic kyphosis in men.

\section{Declarations}

Acknowledgements:

We are grateful to the participants of this studyfor their time and effort. We would like to express special thanks to the employees of the Centre Physical Education of University Economic in Katowice. Also special thanks to Danuta Palica and Joanna Biskup-Dudek.

The present study was conducted according to the Declaration of Helsinki guidelines (Act No 9/2012 of 8 March 2012). The protocol of the study was approved by the Ethics Committee of the Academy of Physical Education. All individuals were informed of the purpose and the nature of the study before giving their written consent to participate.

Consent for publication: Not applicable in this section

Availability of data and materials: Please contact author for data requests.

Funding: The study was supported by the statutory funding from the Jerzy Kukuczka Academy of Physical Education (AWF/IS/ZB2/2020)

Competing interests: The authors declare that they have no competing interests

\section{Authors' contributions:}

JT: participated in the realisation of the study, conceptualization, methodology and participated in the sequence alignment, conceived of the problem of manuscript and participated in its design and coordination and draft the manuscript, visualization

AM: walidation, and formal analysis, data curation, performed the statistical analysis.

AZ: conceived and participated in the realisation of the study, project administration, supervision, funding acquisition

Acknowledgements: We are grateful to the participants of this studyfor their time and effort. We would like to express special thanks to the employees of the Centre Physical Education of University Economic in Katowice. Also special thanks to Danuta Palica and Joanna Biskup-Dudek.

\section{References}


1. Choufani E, Jouve JL, Pomero V, Adalian P, Chaumoitre K, Panuel M. Lumbosacral lordosis in fetal spine: genetic or mechanic parameter. Eur Spine J 2009;18:1342-8; doi.org/10.1007/s00586-0091012-y

2. Cil A, Yazici M, Uzumcugil A, Kandemir U, Alanay A, Alanay $Y$, Acaroglu RE, Surat A. The evolution of sagittal seg $₫$ mental alignment of the spine during childhood. Spine 2005;30(1): 93-100

3. De Cocker KA, Van Uffelen JGZ, Brown WJ. Asscociations between sitting time and weight in young adult Australian Women. Prev Med 2010; 51: 361-367; doi.org/10.1016/j.ypmed.2010.07.009

4. Carpio-Riviera E, Hernandez-Elizondo J, Salicetti-Fonseca A, Solera-Herrera A, Moncada-Jimenez J. Predective validity of body adiposity Index in Costa Rican Students. Am J Hum Biol 2016; 28: 394397; doi.org/10.1002/ajhb.22800

5. Frilander H, Solovieva S, Mutanen P, Pihlakamaki H, Heliovaara M, Viikari-Juntura E. Role of overweight and obesity in low back pain disorders among men: a longitudinal study with life course aproach. BMJ Open 2015; June 13; doi.org/10.1136/bmjopen-2015-007805

6. Chung S-E, Lim C-Y, Kim K, Hwang J, Chung SG: The relationships between low back pain and lumbar lordosis. a systematic review and meta-analysis. Spine J 2017; 17:1180-1191; doi.org/10.1016/j.spinee.2017.04.034

7. Brady SRE, Hussain SM, Brown WJ, Heritier S, Wang Y, Teede H, Urquhart DM, et al. Predictors of back pain in middle-age women: Data from the australian longitudinal study of women's health. Arthritis Care Res 2017; vol.60, no 5: 709-716; doi.org/10.1002/acr.22982

8. Barrey C, Roussouly P,Perrin G,Le Huec J-C. Sagotal balance disorders in severe degenerative spine. Can we identify the compensatory mechanisms? Eur Spine J 2011; 626-633; doi.10.1007//s00586011-1930-3

9. Zwierzchowska A, Tuz J. Evaluation of the impact of sagittal curvatures on musculoskeletal disorders in young people. Med Pr 2018:69(1):29-36; doi.org/10.13075/mp.5893.00558

10. Igic I, RYser S.Elfering A. Does work stress make you shorter? An ambulatory field study of daily work stressors, job control, and spinal shrinkage. JOccup Health Psychol. 2013 Oct; 469-80; doi:10.1037/a0034256.

11. Yokoya M, Higuchi Y. Association between summer temperature and body weight in Japanase adolescents and children: A ecological analysis. Am J Hum Biol. 2016 Nov; 28(6): 789-795; doi:10.1002/ajhb.22867.

12. Compston JE, Flahive J, Hosmer DW, Watts NB, Siris ES, Silverman S. Relationship of weight, height, and body mass idex with fracture risk at different sites in postmenopausal women: the Global Longitudinal study of Osteoporosis in women (GLOW). J Bone Miner Res. 2014: 487-93; doi: 10.1002/jbmr.2051.

13. Donelson R. Rapidly reversible low back pain. An Evidenced-based Pathway to Widespread Recoveries and Savings. 2007; SelfCare First, LLC, Hanover, New Hampshire

14. Been E, Barash A, Pessah H, Peleg S. A new look at the geometry of the lumbar spine. Spine 2010;35:E1014-7; doi.org/10.1097/BRS.0b013e3181ddd433 
15. Le Huec JC, Aunoble S,Philippe L, Nicolas P. Pelvic parameters: origin and significance. Eur Spine J 2011; 20:564-71; doi.org/10.1007/s00586-011-1940-1

16. Giglio CA, Volpon JB. Development and evaluation of thoracic ky- phosis and lumbar lordosis during growth. JChild Orthop2007; 1 (3):18793; doi.org/10.1007/s11832-007-0033-5

17. Mac-Thiong JM, Labelle H, Berthonnaud E, et al. Sagittal spinopel- vic balance in normal children and adolescents. Eur Spine J 2007; 16:227-34; doi:10.1007/s00586-005-0013-8

18. Sinikalloa S, Aalto T, Airaksinen O, Herno A, Kroger H, Savolainen S, Turunen V, Viinamaki H. Somatic comorbidity and younger age are ascociated with life dissatisfaction among with patients with lumbar spinal stenosis before surgical treatment. Euro Spine J. 2007 Jul; 16(7):857-64; doi:10.1007/s00586-006-0080-5

19. Mazur A, Klimek K, Telega G, Filip, Małecka - Tendera E. Ten-Year secular trend of overweight and obesity in school children in south-eastern Poland. Ann Agric Environ Med. (2014):21(3): 634-8; doi: 10.5604/12321966.1120616

20. Malina RM, Reyes ME, Tan SK, Buschang PH, Little BB. Overweight and obesity in a rural Amerindian population in Oaxaca, Southern Mexico, 1968-2000. Am J Hum Biol. 2007; 711-21; doi: 10.1002/ajhb.20622

21. Lehmann A,Floris J, Woitek U, Ruhli FJ, Staub K. Temporal trends, regional variation and socioeconomic differences in height, BMI and body proportions among German conscripts, 1956-2010. Public Health Nutr. 2017; 391-403; doi.org/10.1017/S1368980016002408

22. Avila JA, Avila RA, Goncalves EM, Barbeta VJ, Morcillo AM, Guerra-Junior G. Secular trends of height, weight and BMI in young Brasilian military sudents in 20-th century. Ann Hum Biol. 2013; 554-6; doi:10.3109/03014460.2013.8086

23. Sun SS, Deng X, Sabo R, Carrico R, Schubert CM, Wan W, Sabo C. Secular trends in body composition for children and young adults: the Felts Longitudinal Study. Am J Hum Biol. 2012 Jul-Aug; 24(4):506514; doi:10.1002/ajhb.22256

24. Kowal M, Kryst $\measuredangle$, Sobiecki J, Woronkowicz A. Secular trends in body composition and frequency of overweight and obesity in boys aged 3-18 from Krakow, Poland, within last 30 years (from 1983 to 2010). J Biosoc Sci 2012; 45 (1):1-24; doi:10.1017/S0021932012000284

25. Tutkuviene J. Sex and gender differences in secular trend of body size and frame indices of Lithuanians. Anthropol Anz. 2005 Mar: 63 (1):29-44; www.jstor.org/stable/29542614 